\title{
Collaborative English Writing Based on the Cognitive Process Theory
}

\author{
Ting Sun \\ Faculty of Humanities and Foreign Languages \\ Xi'an University of Technology \\ Xi'an, China 710048
}

\begin{abstract}
This paper set out to study collaborative English writing within the framework of the Cognitive Process Theory of Writing and the Social Constructivist Theory. It found that this teaching method was positively correlated with students' motivation, writing self-efficacy and their writing performance, and negatively correlated with their apprehension. Besides, students held a positive attitude to this model. Therefore, more self-regulated learning strategies should be encouraged to use to ensure students' participation and initiative in collaborative writing process and improve their learning efficiency.
\end{abstract}

Keywords-collaborative learning; English writing; Cognitive Process Theory of Writing; Social Constructivist Theory; selfefficacy

\section{INTRODUCTION}

Among five basic skills of English, writing succeeds in roundly reflecting learners' comprehensive language competence and relates to employment and studying abroad. However, wiring is far from simple linear process but involves intra-linguistic factors like vocabulary, syntax and sections and chapters as well as cross-linguistic factors like learners' metacognition, self-efficacy and anxiety ${ }^{[1]\left(\mathrm{p}^{1-17}\right)}$. At present, teaching approaches adopted in class include product-oriented approach, genre approach and process writing approach. The former two attach importance to students, results and grammar; while the latter stresses writing is a dynamic and social interaction ${ }^{[2]}$, so interaction between learners optimizes their language competence and speech act, in order to improve their comprehensive writing level. Under this background, a new teaching approach of writing, namely collaborative writing appears. Collaborative writing refers to the circulatory social interaction that group members create common text through discussion, negotiation and communication [3] (p66-99). It involves group composition, writing plan, writing strategy, group responsibilities and work pattern.

\section{LITERATURE REVIEW}

\section{A. Theoretical Basis}

Theoretical basis of this research includes Cognitive

[Chinese library classification number] G642.41

[Document code] A

This paper is the research result of teaching research project of Xi' an University of Technology in 2014 "Collaborative English Writing Pattern Based on Weblog" (project number: xqj1414).
Process Theory of Writing and Social Constructivist Theory. Cognitive Process Theory of Writing ${ }^{[4]}$ proposes writing is a complicated circulatory activity instead of linear process and it is process-oriented instead of result-oriented. Writing behavior involves three factors: task environment, long-term memory of author and writing process. Writing process includes plan, translation and inspection ${ }^{[4]}$. Therefore, the key point of writing research is not single text presented by target language but the complicated process involving many factors. Learners are encouraged to collaborate and discuss strategies, in order to seek better writing context. Social Constructivist Theory was proposed by Vygotsky, a social psychologist of former Soviet Union in the mid-twentieth century. Vygotsky ${ }^{[5]}$ believes the development of individual psychology, intelligence and cognition has complicated relationship with social interaction. People will fail to make progress if they divorce from society. $\mathrm{He}$ also proposes the concept of "zone of proximal development", namely the difference between learners' true level and the level that they can reach through getting help. Learners will break through the zone of proximal development and improve cognitive level and learning ability through social assistance and cooperation and interaction with companions ${ }^{[5]}$.

\section{B. Previous Research}

Different researchers have explored from different perspectives. Some researchers mainly discuss the concept and type of collaborative writing ${ }^{[3](\mathrm{p} 66-99)[6](\mathrm{p} 110-138)(\mathrm{p} 19-51)}$; the pattern of collaborative learning between learners ${ }^{[8]}$; how to apply teaching approach of collaborative writing to class and the correlation between this approach with students' writing level ${ }^{[9]}$; how to apply technological means to teaching of collaborative writing. Researches indicate the teaching of collaborative writing based on technological means is positively correlated with students' writing level ${ }^{[10][11][12][13]}$. In China, the combination of blog technology with collaborative writing is also researched. Researches show the teaching approach improves students' writing level and selfefficacy and reduces their anxieties [14] [15] [16]. However, previous researches mainly discuss effectiveness of collaborative writing or correlation between the approach and students' writing level, seldom involving strategies of students' collaborative writing. Besides, few researches are done for English majors. Problems designed according to this research are as follows: 
- Is the teaching approach of collaborative writing more effective than traditional individual writing?

- What is the adjustment strategies used by students in collaborative writing?

- What attitudes students hold toward collaborative writing?

\section{RESEARCH METHODS}

\section{A. Research Objects}

A total of 67 sophomores major in English participate in the research. They are divided into two groups, including Experiment Group ( $n=33)$ and Control Group ( $n=34)$. Control Group is randomly divided into six groups with different numbers of people $(3 \leq n \geq 6)$. It includes 59 female students and 8 male students with age ranging from 18 to 22 . The average age is 19.55 and the standard deviation of age is 1.08. In this research, the Experiment Group receives teaching of collaborative writing for four months, while the Control Group receives traditional teaching of individual writing. All students have learned basic course of English writing for one academic year.

\section{B. Research Tools}

Because analytical information and data information are of equal importance, tools include pre-test, post-test, classroom observation, questionnaire survey and semi-structured interview to get qualitative and quantitative information. First, pretest subjects of the two groups to get familiar with writing levels of participants of Experiment Group and Control Group. Test the two groups after the experiment ends. Posttest is more difficult than pretest because researchers speculate the writing level of learners will improve after four months of writing practice. Students require writing an article, the topics, difficulty and requirements of which are similar to composition of TEM-4, and have to finish within 30 minutes. At the meantime, two questionnaire surveys are designed. Questionnaire survey 1 of Adjustment Strategies Used in Collaborative English Writing is designed for the Experiment

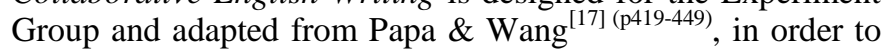
obtain self-adjustment strategies used by them in collaborative learning. The table has nine items and uses Likert scale from one point of "never use" to five points of "use frequently". Questionnaire survey 2 of Students' Attitudes toward Collaborative Learning is also designed for Experiment Group, in order to obtain their attitudes and opinions on collaborative learning. Questionnaire survey 2 has twelve items and uses Likert scale from one point of "object strongly" to five points of "agree strongly". Each questionnaire must be filled within fifteen minutes. Classroom observation is also taken as a tool to record behavior characteristics of collaborative learning in the Experiment Group. The research also uses semi-structured interview to supplement the questionnaire survey to get information at a deeper level. Fifteen students in the Experiment Group are selected randomly to take the interview.

\section{Research Process}

Before researching, pretest Experiment Group and Control Group to get data of original English writing level. The experiment lasts for one semester of four months. Students are required to write eight articles. However, different teaching and writing means are used. Students of the Control Group use traditional method of individual writing, while students of the Experiment Group use method of collaborative writing. Teachers evaluate and comment each article. After four months, the Experiment Group fills in questionnaire surveys 1 and 2. Fifteen students are selected randomly to take the semistructured interview. Post-test the two groups when the process ends.

\section{RESULTS AND ANALYSES}

Researchers think the evaluation of L2 ability is multidimensional and determined by accuracy, complexity and fluency ${ }^{[18][19]}$. Therefore, the three variables are taken as standards to evaluate students' writing. The full mark of each student in the two tests is 100 . The writing of each student is commented and evaluated by two teachers of English language department. The final result is the average score. If the deviation of scores given by two teachers exceeds three points, the third teacher is required to read and appraise again. The final result is the average score of two similar scores.

TABLE I. PRE-TEST AND POST-TEST RESUlTS OF EXPERIMENT GROUP AND CONTROL GROUP

\begin{tabular}{|c|l|c|c|c|c|}
\hline & Group & N & M & SD & $\begin{array}{c}\text { Sig.(two- } \\
\text { tailed) }\end{array}$ \\
\hline Pre-test & EG & 33 & 80.151 & 6.718 & \multirow{2}{*}{.000} \\
\hline & CG & 34 & 82.441 & 6.439 & \\
\hline Post-test & EG & 33 & 84.667 & 6.117 & \multirow{2}{*}{.000} \\
\cline { 1 - 4 } & CG & 34 & 81.147 & 6.257 & \\
\cline { 1 - 3 } & & &
\end{tabular}

According to "Table I", the pre-test results of Experiment Group and Control Group have significant difference (Sig. $=0<0.05)$ : the writing level of Control Group is higher than that of Experiment Group. After four months of experiment, significant differences exist in post-test results between the two groups (Sig. $=0<0.05$ ): the writing level of Experiment Group is higher than that of Control Group. It indicates the writing level of Experiment Group is obviously improved through several months of collaborative learning. The reason why the average score of Control Group declines is that the post-test is more difficult than pre-test. The significant improvement of writing level of the Experiment Group through collaborative training indicates the collaborative writing is more effective than individual writing in classroom teaching.

According to "Table II", in collaborative learning, the strategies most frequently used by students include Goalsetting, organizing and transforming. The strategies least frequently used by students include Co-writing and Rolemaking. The strategy most frequently used is Goal-setting, indicating students will brainstorm within group before writing. According to classroom observation, because all articles are argumentative writing, the contents of discussion include: setting of argument, argument, forms of argument (common knowledge, specific examples, and statistical data), outline and 
reasoning models (inductive reasoning, deductive reasoning). Another strategy frequently used is organizing and transforming, namely understand and communicate through English-Chinese translation.

TABLE II. STRATEGIES OF COLLABORATIVE WRITING

\begin{tabular}{|c|c|c|c|}
\hline Item & Strategies & M & SD \\
\hline $\mathbf{1}$ & Goal-setting & 3.758 & 1.061 \\
\hline $\mathbf{2}$ & Role-making & 2.061 & 0.998 \\
\hline $\mathbf{3}$ & Keeping records & 3.121 & 1.083 \\
\hline $\mathbf{4}$ & Co-writing & 2.060 & 0.998 \\
\hline $\mathbf{5}$ & Error-correcting & 3.000 & 1.146 \\
\hline $\mathbf{6}$ & Seeking information & 2.788 & 1.219 \\
\hline $\mathbf{7}$ & Seeking assistance & 3.000 & 1.000 \\
\hline $\mathbf{8}$ & Reviewing & 2.758 & 1.146 \\
\hline $\mathbf{9}$ & $\begin{array}{c}\text { Organizing and } \\
\text { transforming }\end{array}$ & 3.636 & 0.994 \\
\hline
\end{tabular}

When discussing writing requirements, learners first translate English into Chinese and refer to a dictionary to translate English vocabularies and sentences into Chinese. In collaborative writing, they will translate Chinese into English. It indicates Chinese plays a dominant role in English learning and will promote (positive transfer) or impede (negative transfer) language acquisition. Strategies least frequently used by students are Co-writing and Role-making, indicating they are not familiar with new teaching pattern and tasks and responsibilities of each member and fail to supervise orderly and effective discussion and learning.

TABLE III. STUDENTS' ATTITUDE TOWARD COLLABORATIVE WRITING

\begin{tabular}{|c|c|c|c|}
\hline Item & Attitude & $\mathbf{M}$ & SD \\
\hline 1 & I like the CWM. & 3.576 & 1.324 \\
\hline 2 & I feel confident in $C W$. & 3.363 & 1.410 \\
\hline 3 & I feel less nervous in $C W$. & 3.121 & 1.218 \\
\hline 4 & $\begin{array}{c}\text { I do not have any difficulties in } \\
\text { CW. }\end{array}$ & 2.818 & 1.236 \\
\hline 5 & $\begin{array}{c}\text { I am willing to cooperate with } \\
\text { others in } \mathrm{CW} .\end{array}$ & 3.576 & 1.251 \\
\hline 6 & I did well in $C W$ & 2.424 & 1.146 \\
\hline 7 & $\begin{array}{c}\text { CW can improve my linguistic } \\
\text { ability. }\end{array}$ & 3.090 & 1.283 \\
\hline 8 & $\begin{array}{c}\text { CW can improve my critical } \\
\text { thinking. }\end{array}$ & 3.879 & 1.111 \\
\hline 9 & CW can improve my motivation. & 2.578 & 1.032 \\
\hline 10 & $\begin{array}{c}\text { CW can improve my self- } \\
\text { efficacy. }\end{array}$ & 3.606 & 1.171 \\
\hline 11 & $\begin{array}{c}\text { CW can improve my interest in } \\
\text { writing. }\end{array}$ & 3.182 & 1.261 \\
\hline 12 & $\begin{array}{c}\text { I want to apply } C W \text { to my } \\
\text { classroom. }\end{array}$ & 3.121 & 1.293 \\
\hline
\end{tabular}

According to "Table III", students hold positive attitudes toward collaborative writing and are willing to bring the teaching pattern in class (item $1=3.576$, item $5=3.576$, item $12=3.121$ ). Students will face difficulties in learning (item 4=2.818), indicating the new teaching pattern needs optimizing in practical application. The writing level of Experiment Group through collaborative training is significantly improved, indicating the collaborative writing is more effective than traditional individual writing in classroom teaching. Collaborative learning improves writing level of learners such as the ability to construct morphology, syntax and chapter. The discussion with companions improves their critical thinking, learning motivation, self-efficacy and interests in learning.
Critical thinking, self-efficacy and learning interest have the highest numerical values, indicating in collaborative writing, different opinions and perspectives of group members broaden horizon of them and strengthen the hierarchy of thinking. Meanwhile, the interaction reduces students' anxiety in individual writing and improves their self-efficacy in writing. Researches show self-efficacy of writing is positively correlated with writing level and interests [20] (p163-175) [21] [22] [23] (p40-47). Students with high self-efficacy are more confident to accept challengeable tasks and more willing to make efforts and have persistence and willpower more easily, so it is easy for them to make success in academically.

\section{CONCLUSION}

The experimental results indicate collaborative writing teaching is positively correlated with students' performance. Students also hold positive attitude toward this pattern. It improves students' expression ability through vocabulary, syntax and chapter and their ability in critical thinking. Meanwhile, the relaxed environment reduces learners' anxiety and increases their motivation and interests as well as selfefficacy, which have positive influence on writing. In order to apply the teaching approach in class more effectively, first, teachers should organize and guide students' behaviors; second, optimize grouping mode and furthest stimulate students' enthusiasm in participation; third, encourage students to use various self-adjustment strategies, in order to write and learn orderly and effectively.

\section{REFERENCES}

[1] Stewart, G., Steifert, A. T. \& Rolheiser, C. (2015). Anxiety and selfefficacy's relationship with undergraduate students' perceptions of the use of metacognitive writing strategies. The Canadian Journal for the Scholarship of Teaching and Learning, 6(1), 1-17

[2] Hyland, K. (2005). Teaching and Researching Writing. Beijing: Foreign Language Teaching and Research Press.

[3] Lowry, P. B., Curtis A. \& Lowry, M. R. (2004). Building a taxonomy and nomenclature of collaborative writing to improve interdisciplinary research and practice. Journal of Business Communication, 1, 66-99.

[4] Flower L. \& Hayes J. R. (1981). A cognitive process theory of writing. College Composition and Communication, 32(4).

[5] Vygotsky L. S. (1978). Mind in Society: The Development of Higher Psychological Process. Cambridge, MA: Harvard University Press.

[6] Galegher, J.\& Kraut, R. E. (1994). Computer-mediated communication for intellectual teamwork: an experiment in group writing. Information Systems Research, 5(2),110-138.

[7] Tammaro, S. G., Moseir, J. N. C. \& Spitz, G. (1997). Collaborative writing is had to support: a field study of collaborative writing computer, Supported Cooperative Work. The Journal of Collaborative Computing, 6, 19-51.

[8] Posner, H. R. \& Baecher, R.M. (1993). How people write together, In R.M.Backer (ed.): Readings in Groupware and Computer-supported Cooperative Work: Assisting Human-Human Collaboration.

[9] Ede, L. \& Lunsford, A. (1990). Singular Texts/Plural Authors: Perspectives on Collaborative Writing. Carbondale, IL: Southern Illinois University Press.

[10] Campbell, C. (2003). Teaching Second Language Writing: Interacting with Text. Beijing: Foreign Language Teaching and Research Press.

[11] Johnson, A. (2004). Creating a writing course utilizing class and student blogs, The Internet TESL Journal,8,from http://iteslj.org/Techniques/Johnson-Blogs/. 
[12] Stanley, G. (2005). Blogging for ELT, from http://www.teachingenglish.org.uk/think/resources/blogging.shtml.

[13] Ward, J. (2006). Having a BALL with Blog-Assisted Language Learning, from http://www.bedfordstmartins.com/lore/digressions/content.htm?dis13.

[14] Gu Jixin. (2002), New Teaching Methods of English Writing: Online Writing Laboratory, Computer-assisted Foreign Language Education, 87

[15] Tan Cuiyan, 2006, Integration of Blogs with College English Teaching, Data of Culture and Education, 7

[16] Shen Guohuan, Zhang Shuntao (2006), Role of "Blogs" in Teaching of College English Writing, Introduction of Educational Technology, 4

[17] Pape, S. J. \& Wang, C. (2003). Middle school children's strategic behavior: Classification and relation to academic achievement and mathematical problems-solving. Instructional Science, 31, 419-449.

[18] Ellis, R. (2003). Task-based language Learning and Teaching. Oxford: Oxford University Press.

[19] Ellis, R. \& Barkhuizen, G. (2005). Analysing Learner Language. Oxford: Oxford University Press.

[20] Pajares, F. \& Johnson, M. J. (1996). Self-efficacy beliefs and the writing performance in entering high school students. Psychology in the Schools 33, 163-175.

[21] Pajares, F., \& Valinante, G. (1997). Influence of self-efficacy on elementary students' writing. The Journal of Educational Research, 90.

[22] Li, H., Liu, R., \& Liu, Y. (2013). The mediating effects of EFL writing self-efficacy on the relationship between EFL writing anxiety and writing performance for college students. Psychological Development and Education, 4, 385-390.

[23] Yan, R., \& Zhang, L. (2015). The effect of complexity and difficulty of tasks, and self-efficacy on English writing. Foreign Language World, 1, 40-47. 